\title{
Decreased serum levels of sex steroids associated with osteoporosis in a group of Romanian male patients
}

\section{Nivele serice scăzute ale sexsteroizilor asociate cu osteoporoza la un grup de bărbați din Romania}

\author{
Florina Ligia Popa ${ }^{1}$, Mihaela Stanciu², Adrian Bighea ${ }^{3}$, Mihai Berteanu ${ }^{4}$, Ioan \\ Gheorghe Totoianu 5 , Maria Rotaru ${ }^{6}$
}

\begin{abstract}
1. Lucian Blaga University of Sibiu, Romania, Faculty of Medicine Victor Papilian of Sibiu, Department of Physical Medicine and Rehabilitation; 2. Lucian Blaga University of Sibiu, Romania, Faculty of Medicine Victor Papilian of Sibiu; 3. University of Medicine and Pharmacy, Craiova, Romania, Department of Physical Medicine and Rehabilitation; 4. "Carol Davila" University of Medicine and Pharmacy, Bucharest, Romania, Department of Physical Medicine and Rehabilitation;

5. Lucian Blaga University of Sibiu, Romania, Faculty of Medicine Victor Papilian of Sibiu, Department of Endocrinology; 6. Lucian Blaga University of Sibiu, Romania, Faculty of Medicine Victor Papilian of Sibiu, Department of Dermatology
\end{abstract}

\begin{abstract}
Introduction. With age, sex hormone deficiency leads to reduced bone mineral density (BMD) in men. The aim of our research is to analyze the role of serum sex steroids in assessing BMD in the men included in this study. Materials and methods. This cross-sectional study included 146 men aged 65-85 years old with osteopenia or osteoporosis (study group) and 121 men with normal BMD (control group). Serum levels of total testosterone (Tt) and free testosterone (Tf) were measured by immunoassay, and estradiol (E2) levels were measured by the immunoenzymatic method. Femoral neck and lumbar spine BMD was examined by dual-energy X-ray absorptiometry. Results. Tf and E2 deficiency was significantly associated with low BMD ( $p=0.007)$. No association was found between Tt deficiency and reduced BMD. Tf levels $(p<0.001)$ and E2 levels $(p=0.003)$ were significantly lower in patients with reduced BMD compared to those with normal BMD. Significant more cases with low levels of Tf $(p=0.015)$ and E2 $(p<0.001)$ were found in patients with osteoporosis compared to those with osteopenia. Conclusions. Sex hormones deficiency in men was significantly correlated with the decrease of BMD. Determination of serum Tf and E2 levels is important in assessing the risk of osteoporosis in male subjects.
\end{abstract}

Keywords: sex steroids; bone mineral density;men

\section{Rezumat}

Introducere. Odată cu înaintarea în vârstă deficitul de hormoni sexuali conduce la reducerea densității minerale osoase (DMO) la bărbați.

*Corresponding author: Mihaela Stanciu, Lucian Blaga University of Sibiu, Faculty of Medicine Victor Papilian of Sibiu, Sibiu, Romania, e-mail: mihaela.stanciu@yahoo.com; florina.popa@yahoo.com 
Scopul cercetării noastre este de a analiza rolul sexsteroizilor serici în evaluarea DMO la bărbații incluși în studiu. Material și metode. Acest studiu retrospectiv transversal a inclus 146 bărbați cu vârsta cuprinsă între 55-85 ani diagnosticați cu osteoporoză sau osteopenie (grupul studiu) și 121 bărbați cu DMO normală (grupul control). Nivelele serice ale testosteronului total (Tt), testosteronului liber (Tf) au fost determinate prin teste imunologice și ale estradiolului (E2) prin metoda imunoenzimatică. DMO la nivelul colului femural și a coloanei lombare a fost masurată prin absobțiometrie duală cu raze X.

Rezultate. Deficitul Tf și E2 a fost asociat semnificativ statistic cu DMO scăzută $(p=0.007)$. Nu a fost constatată nici o asociere între deficitul de Tt și DMO scăzută. Nivelurile serice ale Tf $(p<0.001)$ și ale E2 ( $p=0.003)$ au fost semnificativ mai scăzute la bărbații cu DMO redusă comparativ cu cei cu DMO normală. Semnificativ mai multe cazuri cu Tf scăzut și E2 scăzut au fost întâlnite în rândul pacienților cu osteoporoză comparativ cu cei cu osteopenie.

Concluzii. Deficitul de sexsteroizi la bărbați a fost semnificativ corelat cu scăderea DMO. Determinarea nivelelor serice ale Tf și E2 este importantă în evaluarea riscului de osteoporoză la bărbați.

Cuvinte cheie: sexsteroizi; densitate minerală osoasă;bărbați

Received: $16^{\text {th }}$ September 2015; Accepted: $16^{\text {th }}$ February 2016; Published: $12^{\text {th }}$ March 2016

\section{Introduction}

Sex hormones deficiency is recognized as one of the major etiological factors of male osteoporosis, in this case trabecular connectivity being seriously impaired [1-4]. It is known that, with age, there appears a gradual decline in testosterone production and bone mineral density (BMD) [5]. Therefore, the reduced trophic role of androgens on muscle determines an increased risk for falling and the appearance of osteoporotic fractures [6].

The decrease of estradiol $\left(\mathrm{E}_{2}\right)$, derived from the conversion of testosterone under the influence of aromatase at target cells level (skin, fat, skeleton) brings about the reduction of antiresorptive effect and consequently the reduction of BMD $[2,7,8]$. Clinical and basic research demonstrates that $\mathrm{E}_{2}$ is the main sex steroid required for bone homeostasis in men. The progressive decline of testosterone that usually occurs with advancing age might result in a corresponding decrease of circulating estrogens in men [9]. Both estradiol and testosterone are indispensable for the maintenance of bone health status in men [10-12]. Relative estrogen deficiency in elderly men with low testosterone is common and has been clearly demonstrated in most of the longitudinal studies on sex steroids in older men [9].

In older men, $70-85 \%$ of the decrease in BMD related to sex steroids decline is imputable to estrogen deficiency, while only the remaining $15-30 \%$ is imputable to androgens. Data obtained from older men demonstrate that $\mathrm{E}_{2}$ is inversely associated with BMD [13] and seems to predict fractures better than testosterone [14].

Elderly males might present relative estrogen deficiency that may be involved in several age-related conditions [15] that can affect and worsen quality of life, including bone loss.

The role of sex steroids deficiency on bone turnover in men is inconclusive. Some studies support the hypothesis that low sex hormones levels are associated with reduced BMD [16]. In other researches, sex steroids levels were found not to be related to BMD and fracture risk $[17,18]$.

To our knowledge, there have not been any studies on the effects of sex steroids on BMD in Romanian males. For this reason, our research aims at analyzing the role of sex steroids serum levels in evaluating osteoporosis in the men included in the study. 


\section{Materials and methods}

This retrospective cross-sectional clinical study was conducted between 2008-2012 and enrolled 146 men who were diagnosed, by Dual-energy X-ray absorptiometry (DXA) method, with osteoporosis (T score $\leq-2.5 \mathrm{SD}$ ) or osteopenia $(-2.5 \mathrm{SD}<\mathrm{T}$ score $<-1 \mathrm{SD})$ (study group) and a control group that included 121 men with normal bone mineral density ( $T$ score $\geq-1 \mathrm{SD}$ ). All subjects were evaluated after having given their informed consent. Patients' age ranged between 65 and 85 years old.

Inclusion criteria for the study group were the diagnosis of osteoporosis or osteopenia established by DXA method and for the control group, the normal values of BMD.

Exclusion criteria for both groups were neoplasia regardless of stage or location and psychiatric disorders that would affect cognitive ability and patients' compliance.

Patients' evaluation included: medical history and physical examination. The following anthropometric measurements were carried out: body mass and height to calculate the body mass index (BMI) expressed as body mass (kg) / square of body height $\left(\mathrm{m}^{2}\right)$. The measurements were performed in subjects without top clothing and shoes.

BMD was measured by a LUNAR DPX-NT densitometer (Medtel, Australia) in all patients included in the study. The DXA scans were obtained by standard procedures by the manufacturer for scanning and analysis. Patients' BMD was measured at the lumbar spine (anteroposterior projection at L1-L4) and at the femurs (i.e., femoral neck, trochanter, and total hip). The World Health Organization (WHO) classification system was applied, defining osteoporosis as $\mathrm{T}$ score $\leq-2.5$ and osteopenia as $-2.5<\mathrm{T}$ score $<-1$.

Blood for laboratory investigations was collected from the median cubital vein between 7.00 and 9.00 a.m. after overnight fasting (last meal on the preceding day at 6 p.m.) and the serum was stored until examinations at $-20^{\circ} \mathrm{C}$.

Hormonal investigations were carried out using a COBAS 6000 analyzer (Roche Diagnostics). Concentrations of total testosterone $(\mathrm{Tt})$, free testosterone (Tf) were measured by the competitive immunochemical electrochemiluminescence method (ECLIA). $\mathrm{E}_{2}$ serum concentration was measured by a competitive immunoenzymatic method (ELISA).

Sex steroid deficiency was considered: for $\mathrm{Tt}$ - below $2.25 \mathrm{ng} / \mathrm{ml}$, for Tf - below $5.472 \mathrm{ng} / \mathrm{L}$, and for $\mathrm{E}_{2}$ - below $28 \mathrm{pmol} / \mathrm{L}$.

\section{Statistical analysis}

The data were processed using International Business Machines - Statistical Package for the Social Sciences version 18.0, 2010 (IBM-SPSS 18.0, Armonk, New York, USA). The value of statistical significance was set at $p<0.05$. The mathematical values of tests were declared for significant comparisons. For the parametric comparison, we used the t-test. For ordinal or non-parametric data, we used the Mann-Whitney test for comparing the two groups. Chi-square test was used in tables $2 * 2$ with ordinal / nominal data. Multivariate analyses were performed using multiple logistic regression method, with the calculation of OR (CI95\%).

\section{Results}

Upon analyzing the results, we found that the mean age of the patients included in the study was $72.9 \pm 5.1$ years. No significant differences were found between the two groups regarding BMI (Table 1).

The results revealed that mean lumbar BMD is significantly lower in the study group, when compared to the control group, $\mathrm{U}=8, \mathrm{z}=-13.9$, $\mathrm{p}<0.001, \mathrm{r}=0.85$, the size effect being very large. Mean hip BMD is also significantly lower in the study group in comparison to the control group, 
Table 1. Mean value of age, BMI, sex steroids and DXA parameters in patients with osteoporosis and osteopenia: study group and control group

\begin{tabular}{lccc}
\hline Variable & Study group & Control group & p \\
\hline Age $($ years $)$ & $73.48 \pm 5.160$ & $72.12 \pm 4.929$ & $0.03^{*}$ \\
\hline BMI $(\mathrm{kg} / \mathrm{m} 2)$ & $25.69 \pm 3.64$ & $25.79 \pm 2.68$ & 0.800 \\
\hline Lumbar BMD $\left(\mathrm{g} / \mathrm{m}^{2}\right)$ & $0.91 \pm 0.068$ & $1.14 \pm 0.02$ & $<0.001^{*}$ \\
\hline Hip BMD $\left(\mathrm{g} / \mathrm{m}^{2}\right)$ & $0.80 \pm 0.07$ & $0.98 \pm 0.02$ & $<0.001^{*}$ \\
\hline Total Testosterone $(\mathrm{Tt})(\mathrm{ng} / \mathrm{ml})$ & $3.98 \pm 1.41$ & $4.34 \pm 1.35$ & 0.061 \\
\hline Free Testosterone $(\mathrm{Tf})(\mathrm{ng} / \mathrm{L})$ & $6.56 \pm 2.76$ & $7.65 \pm 2.44$ & $<0.001^{*}$ \\
\hline Estradiol $\left(\mathrm{E}_{2}\right)(\mathrm{pmol} / \mathrm{L})$ & $38.35 \pm 16.60$ & $45.70 \pm 10.76$ & $0.003^{*}$ \\
\hline
\end{tabular}

Values are expressed as mean $\pm \mathrm{SD}$;

$* \mathrm{p}<0.05$ Statistically significant

$\mathrm{U}=376.5, \mathrm{z}=-13.5, \mathrm{p}<0,001, \mathrm{r}=0.82$, the size effect being very large (Table 1 ).

Men with decreased BMD were older, the mean age being significantly higher in study group compared to control group, $\mathrm{t}(265)=2.18$, $\mathrm{p}=0.03$ (Table 1). However, if we compare the two groups depending on age groups, the difference is not significant. Also, when comparing the two groups according to the BMI categories, the difference is not statistically significant (Table 2).

No significant differences were found between the study group and the control group regarding mean $\mathrm{Tt}(3.98 \mathrm{ng} / \mathrm{ml}$ for the study group compared with $4.34 \mathrm{ng} / \mathrm{ml}$ for the control group; $\mathrm{p}=0.061$ ). Tf levels were significantly lower in the study group when compared with the control group (6.56 ng/L vs. $7.65 \mathrm{ng} / \mathrm{L}$, respectively), $\mathrm{U}=6207, \mathrm{z}=-4.18, \mathrm{p}<0.001, \mathrm{r}=0.25$, size effect being small to medium. Mean $\mathrm{E}_{2}$ levels were significantly lower in the study group (38.53 $\mathrm{pmol} / \mathrm{L})$ compared to the control group (45.70 $\mathrm{pmol} / \mathrm{L}), \mathrm{U}=6942.5, \mathrm{z}=-3.01, \mathrm{p}=0.003, \mathrm{r}=0.18$, the size effect being small (Table 1). These results demonstrate a significant association between reduced BMD and lower mean levels of $\mathrm{Tf}$ and E2 in men, but no association between low BMD and $\mathrm{Tt}$.

Sex hormones deficiency (at least one sex steroid below normal level) was found in $45.21 \%$ of cases in patients with low BMD (from the study group) compared to a rate of $24.5 \%$ in the control group $(\mathrm{p}=0.001)$ (Table 2$)$.

The distribution of patients on lower than normal and normal categories of $\mathrm{Tt}$ was not significantly different among groups $(p=0.088$; low value for 22 patients $-15.1 \%$ from the study group compared with 10 patients $-8.3 \%$ from the control group). Lower Tf levels were 1.95 times more frequent in the study group, when compared to the control group, $\chi^{2}(1)=7.2, p=0.007$ (low value for 82 patients - 56.2\% from the study group compared with 48 patients $-39.7 \%$ from the control group). For the study group, OR was lower than the normal value of $\mathrm{Tf}$ (OR: 1.35; CI95\%: 1.081 and 1.686) (Table 2).

Lower $\mathrm{E}_{2}$ levels were 6.88 times more frequent in the study group in comparison to the control group, $\chi^{2}(1)=7.2, p=0.007$. Thus, 52 patients $(35.6 \%)$ with altered parameter on DXA (study group) presented low $\mathrm{E}_{2}$ compared with 9 patients $(7.4 \%)$ of the control group. For the study group, OR was lower than the normal value of $E_{2}$ (OR: 1.86; CI95\%: 1.557 and 2.241) (Table 2). These results reflect that the Tf and $\mathrm{E}_{2}$ deficiency were significantly correlated with low BMD.

Compared to the control group, the study group (with reduced BMD) had a higher number of patients with low serum levels of steroid sexual hormones, $U=5855, \mathrm{z}=-5.08, \mathrm{p}<0.001$ (Table 
Table 2. Demographic and clinical characteristics of study and control groups

\begin{tabular}{|c|c|c|c|c|c|c|}
\hline \multicolumn{2}{|c|}{ Variable } & \multicolumn{2}{|c|}{ Study group } & \multicolumn{2}{|c|}{ Control group } & $\mathbf{p}$ \\
\hline \multicolumn{2}{|l|}{ Absolute frequency } & \multicolumn{2}{|c|}{146} & \multicolumn{2}{|c|}{121} & \\
\hline \multirow{2}{*}{ Age } & $65-75$ & 81 & $55.5 \%$ & 80 & $66.1 \%$ & \multirow{2}{*}{0.077} \\
\hline & $75-85$ & 65 & $44.5 \%$ & 41 & $33.9 \%$ & \\
\hline \multirow{4}{*}{ BMI } & underweight & 4 & $2.7 \%$ & 0 & $0.0 \%$ & \multirow{4}{*}{0.120} \\
\hline & normal & 56 & $38.4 \%$ & 50 & $41.3 \%$ & \\
\hline & overweight & 70 & $47.9 \%$ & 64 & $52.9 \%$ & \\
\hline & obese & 16 & $11.0 \%$ & 7 & $5.8 \%$ & \\
\hline \multirow{2}{*}{$\begin{array}{l}\text { Sex steroids } \\
\text { deficiency }\end{array}$} & Yes & 66 & $45.2 \%$ & 30 & $24.8 \%$ & \multirow{2}{*}{$0.001 *$} \\
\hline & No & 80 & $54.8 \%$ & 91 & $75.2 \%$ & \\
\hline \multirow{2}{*}{$\begin{array}{l}\text { Total Testosterone } \\
(\mathrm{Tt})\end{array}$} & Normal & 124 & $84.9 \%$ & 111 & $91.7 \%$ & \multirow{2}{*}{0.088} \\
\hline & Low & 22 & $15.1 \%$ & 10 & $8.3 \%$ & \\
\hline \multirow{2}{*}{$\begin{array}{l}\text { Free Testosterone } \\
\text { (Tf) }\end{array}$} & Normal & 64 & $43.8 \%$ & 73 & $60.3 \%$ & \multirow{2}{*}{$0.007^{*}$} \\
\hline & Low & 82 & $56.2 \%$ & 48 & $39.7 \%$ & \\
\hline \multirow{2}{*}{ Estradiol $\left(\mathrm{E}_{2}\right)$} & Normal & 94 & $64.4 \%$ & 112 & $92.6 \%$ & \multirow{2}{*}{$0.007^{*}$} \\
\hline & Low & 52 & $35.6 \%$ & 9 & $7.4 \%$ & \\
\hline \multirow{4}{*}{$\begin{array}{l}\text { Number of lower } \\
\text { than normal sex } \\
\text { steroids }\end{array}$} & 0 & 42 & $28.8 \%$ & 73 & $60.3 \%$ & \multirow{4}{*}{$<0.001 *$} \\
\hline & 1 & 64 & $43.8 \%$ & 33 & $27.3 \%$ & \\
\hline & 2 & 28 & $19.2 \%$ & 11 & $9.1 \%$ & \\
\hline & 3 & 12 & $8.2 \%$ & 4 & $3.3 \%$ & \\
\hline
\end{tabular}

$* \mathrm{p}<0.05$ Statistically significant

2). $\mathrm{T}$ score analysis in the study group revealed that $30.1 \%$ of men ( 44 cases) had osteopenia and $69.9 \%$ of patients (102 cases) presented osteoporosis.

We found no differences between distribution of $\mathrm{Tt}$ categories among classes of osteopenia and osteoporosis. Significantly more cases with low Tf were found in the osteoporosis group compared to the osteopenia group, $\chi^{2}(1)=5.95, p=0.015$. For the osteoporosis class,
OR was lower than normal value of Tf (OR: 1.31; CI95\%: 1.041 and 1.659). Significant more cases of low levels of $E_{2}$ were found in the osteoporosis group, when compared with the osteopenia group, $\chi^{2}(1)=19.32, p<0.001$. For the osteoporosis class, OR was lower than normal value of E2 (OR: 1.61; CI95\%: 1.32 and 1.95) (Table 3). These results demonstrate that osteoporosis is positively correlated with $\mathrm{Tf}$ and $\mathrm{E}_{2}$ deficiency.

Table 3. Distribution of sex steroids categories among classes of osteoporosis and osteopenia

\begin{tabular}{|c|c|c|c|c|c|c|}
\hline \multirow{3}{*}{$\begin{array}{l}\text { Total testosterone } \\
\text { categories }\end{array}$} & \multirow[b]{2}{*}{ Low } & \multicolumn{2}{|c|}{ Osteopenia } & \multicolumn{2}{|c|}{ Osteoporosis } & \multirow{2}{*}{$\frac{\mathbf{p}}{0.185}$} \\
\hline & & 4 & $9.1 \%$ & 18 & $17.6 \%$ & \\
\hline & Normal & 40 & $90.9 \%$ & 84 & $82.4 \%$ & \\
\hline \multirow{2}{*}{$\begin{array}{l}\text { Free testosterone } \\
\text { categories }\end{array}$} & Low & 18 & $40.9 \%$ & 64 & $62.7 \%$ & $0.015^{*}$ \\
\hline & Normal & 26 & $59.1 \%$ & 38 & $37.3 \%$ & \\
\hline \multirow[t]{2}{*}{ Estradiol categories } & Low & 4 & $9.1 \%$ & 48 & $47.1 \%$ & $<0.001^{*}$ \\
\hline & Normal & 40 & $90.9 \%$ & 54 & $52.9 \%$ & \\
\hline
\end{tabular}

\footnotetext{
$* \mathrm{p}<0.05$ Statistically significant
} 


\section{Discussions}

Sex steroids deficiency represents, according to literature, a high incidence risk factor for osteoporosis in men $[5,7,10,11,19,20]$. According to some authors, bone density, rate of bone loss and incidence of fractures are better correlated with serum estradiol level than with testosterone level $[21,22]$. We observed a statistically significant correlation between sex hormones deficiency and the reduction of bone density $(p=0.001)$, comparable with the results of other reports $[4,6,23]$.

We have demonstrated that BMD reduction is associated with sex steroids deficiency, in particular with decreased serum levels of $\mathrm{Tf}$ and $E_{2}$. These results are consistent with other studies that have found a positive association between serum levels of $\mathrm{Tf}$ and BMD [16,2427]. However, many researches $[17,28,29]$ have shown a positive correlation between $\mathrm{E}_{2}$ and BMD, whereas other authors [24,26] reported the absence of this association. Another research showed that low levels of $\mathrm{Tf}$ and free estradiol and high levels of SHBG were associated with low BMD [30].

No association between low BMD and $\mathrm{Tt}$ was found in our research. Regarding $\mathrm{Tt}$, there are publications which revealed a lack of association with BMD [24,26,30], however others $[16,31]$ proved that low levels of this hormone are accompanied with low BMD.

A study conducted on a sample of 976 men aged between 30 and 79 years showed that $\mathrm{Tt}$ and Tf serum levels did not correlate with BMD, instead total and free estradiol was strongly correlated with BMD especially in the total hip and femoral head [32].

Our results showed that levels of $\mathrm{Tf}$ and $\mathrm{E}_{2}$ were lower in men with reduced BMD compared to men with normal BMD. A prior study involved 2447 men aged over 65 years old and assessed the levels of $\mathrm{Tt}$ and total estradiol in those with low BMD compared to those with normal BMD.
The prevalence of osteoporosis was significantly higher in both men with Tt deficiency and those with low total estradiol [33].

A research which included 609 men aged over 60 revealed that low testosterone is associated with increased risk of fracture, particularly with hip and non-vertebral ones [4]. These results suggest that the effect of testosterone on fracture risk in elderly men may be mediated by non-skeletal factors, such as muscle strength and/or risk of falling.

Our study has as limitation the lack of free estradiol and sex hormone binding globulin (SHBG) determination, which restricted the analysis of the role of these factors in the development of osteoporosis in men.

In conclusion, our study showed that sex steroids deficiency in our group of male patients is associated with bone loss. It can be stated that $\mathrm{Tf}$ and $\mathrm{E}_{2}$ are more important than Tt in assessing the risk of osteoporosis in male subjects. Sex steroids measurement might be useful for identifying men at higher risk for osteoporosis.

\section{Conflicts of interest}

The authors declare that they have no conflict of interest.

\section{Abbreviations}

BMD - bone mineral density

$\mathrm{E}_{2}$ - estradiol

DXA - Dual-energy X-ray absorptiometry

BMI - body mass index

WHO - World Health Organization

$\mathrm{Tt}$ - total testosterone

Tf - free testosterone

ECLIA - Electrochemiluminescence immunoassay

ELISA - Enzyme-linked Immunosorbent Assay IBM-SPSS - International Business Machines-Statistical Package for Social Sciences SHBG - sex hormone binding globulin 


\section{References}

1. Rao SS, Budhwar N. Ashfaque A. Osteoporosis in men. Am Fam Physician. 2010 Sep 1;82(5):503-508.

2. Herrera A, Lobo-Escolar A, Mateo J, Gil J, Ibarz E, Gracia L. Male osteoporosis: A review. World J Orthop. 2012 December 18;3(12):223-34. DOI: 10.5312/wjo. v3.112.223

3. Lambert JK, Zaidi M, Mechanick JI. Male osteoporosis: epidemiology and the pathogenesis of aging bones. Curr Osteoporos Rep. 2011 Dec;9(4):229-36. DOI: 10.1007/s11914-011-0066-Z

4. Meier C, Nguyen TV, Handelsman DJ, Schindler C, Kushnir MM, Rockwood AL, et al. Endogenous Sex Hormones and Incident Fracture Risk in Older Men. The Dubbo Osteoporosis Epidemiology Study. Arch Intern Med. 2008 Jan;168(1):47-54. DOI: 10.1001/ archinternmed.2007.2

5. Martin AC. Osteoporosis in men: a review of endogenous sex hormones and testosterone replacement therapy. J Pharm Pract. 2011 Jun; 24(3):307-15. DOI: $10.1177 / 0897190010397716$

6. Drake MT, Murad MH, Mauck KF, Lane MA, Undavalli $\mathrm{C}$, Elraiyah T, et al. Clinical review. Risk factors for low bone mass-related fractures in men: a systematic review and meta-analysis. J Clin Endocrinol Metab. 2012 Jun;97(6):1861-70. DOI: 10.1210/jc.2011-3058

7. Frenkel B, Hong A, Baniwal SK, Coetzee GA, Ohlsson $\mathrm{C}$, Khalid O, et al. Regulation of adult bone turnover by sexsteroids. J Cell Physiol. 2010;224(2):305-10. DOI: $10.1002 /$ jcp. 22159

8. Khosla S, Oursler MJ, Monroe DG. Estrogen and the skeleton. Trends Endocrin Met. 2012; 23(11):576-81. DOI: 10.1016/j.tem.2012.03.008

9. Rochira V, Balestrieri A, Madeo B, Zirilli L, Granata ARM, Carani C. Osteoporosis and male age-related hypogonadism: role of sex steroids on bone (patho) physiology. Eur J Endocrinol. 2006 Febr;154(2):175-85. DOI: 10.1530/eje.1.02088

10. Chin KY, Ima-Nirwana S. Sex Steroids and Bone Health Status in Men. Int J Endocrinol. 2012; 10:40410. DOI: $10.1155 / 2012 / 208719$

11. Carnevale V, Romagnoli E, Cipriani C, Del Fiacco R, Piemonte S, Pepe J, et al. Sex hormones and bone health in males. Arch Biochem Biophys. 2010;503:110-7. DOI: $10.1016 /$ j.abb.2010.07.001

12. El Maghraoui A, Ouzzif Z, Mounach A, Ben-Ghabrit A, Achemlal L, Bezza A, et al. The relationship between sex steroids, bone turnover and vertebral fracture prevalence in asymptomatic men. Bone. 2011 Oct;49(4):8537. DOI: 10.1016/j.bone.2011.06.022

13. Ward KA, Pye SR, Adams JE. Influence of age and sex steroids on bone density and geometry in middle-aged and elderly European men. Osteoporos Int. 2011 May;22(5):1513-23. DOI: 10.1007/s00198-0101437-5
14. Barrett-Connor E, Mueller JE, von Mühlen DG, Laughlin GA, Schneider DL, Sartoris DJ. Low levels of estradiol are associated with vertebral fractures in older men, but not women: the Rancho Bernardo Study. J Clin Endocrinol Metab. 2000 Jan;85(1):219-23. DOI: 10.1210/jc.85.1.219 DOI: 10.1210/jcem.85.1.6327

15. Finkelstein JS, Lee H, Burnett-Bowie SAM. Gonadal steroids and body composition, strength, and sexual function in men. N Engl J Med. 2013 Sep;369(11):101122. DOI: $10.1056 /$ NEJMoa1206168

16. Mellstrom D, Johnell O, Ljunggren O, Eriksson AL, Lorentzon M, Mallmin H, et al. Free testosterone is an independent predictor of BMD and prevalent fractures in elderly men: MrOS Sweden. J Bone Miner Res. 2006 Apr;21(4):529-35. DOI: 10.1359/jbmr.060110

17. Goderie-Plomp HW, van der Klift M, de Ronde W, Hofman A, de Jong FH \& Pols HAP. Endogenous sex hormones, sex hormone binding globulin, and the risk of incident vertebral fractures in elderly men and women: the Rotterdam Study. J Clin Endocrinol Metab. 2004 Jul;89(7):3261-9. DOI: 10.1210/jc.2002-022041

18. Ree EJ, Oh KW, Lee WY, Kim SW, Oh ES, Baek KH, et al. Age, body mass index, current smoking history, and serum insulin-like growth factor-I levels associated with bone mineral density in middle-aged Korean men. J Bone Miner Metab. 2004;22(4):392-8. DOI: 10.1007/ s00774-003-0500-0

19. Compston J, Bowring C, Cooper A, Cooper C, Davies $\mathrm{C}$, Francis R, et al. Guidelines for the diagnosis and management of osteoporosis in postmenopausal women and older men in the UK: National Osteoporosis Guideline Group (NOGG). Maturitas. 2013 Aug;75(4):392-6. DOI: $10.1016 /$ j.maturitas.2013.05.013

20. Gielen E, Vanderschueren D, Callewaert F, Boonen S. Osteoporosis in men. Best Practice and Research 2011; 25(2):321-35. DOI: 10.1016/j.beem.2010.08.012

21. Khosla S. Update in male osteoporosis. J Clin Endocrinol Metab. 2010 Jan;95(1):3-10. DOI: 10.1210/ jc. $2009-1740$

22. Sutton RAL, Dian L, Guy P. Osteoporosis in men: An underrecognized and undertreated problem. BCMJ. 2011 Dec;53(10):535-40.

23. Woo J, Kwok T, Leung JCS, Ohlsson C, Vandenput L, Leung PC. Sex steroids and bone health in older Chinese men. Osteoporosis International 2011; 23(5):1553-62. DOI: $10.1007 / \mathrm{s} 00198-011-1552-\mathrm{y}$

24. Bjornerem A, Emaus N, Berntsen GK, Joakimsen RM, Fonnebo V, Wilsgaard T, et al. Circulating sex steroids, sex hormone-binding globulin, and longitudinal changes in forearm bone mineral density in postmenopausal women and men: the Tromso study. Calcif Tissue Int. 2007 Aug;81(2):65-72. DOI: 10.1007/s00223-0079035-z

25. Cauley JA, Ewing SK, Taylor BC, Fink HA, Ensrud $\mathrm{KE}$, Bauer DC, et al. Sex steroid hormones in older men: Longitudinal associations with 4.5 -year change in 
hip bone mineral density-The Osteoporotic Fractures in Men Study (MrOs). J Clin Endocrinol Metab. 2010 Sep;95(9):4314-23. DOI: 10.1210/jc.2009-2635

26. Keles I, Aydin G, Basar MM, Hairan M, Atalar E, Orkun S, et al. Endogenous sex steroids and bone mineral density in healthy men. Joint Bone Spine. 2006 Jan;73(1):80-5. DOI: 10.1016/j.jbspin.2005.04.003

27. Venkat K, Desai M, Arora MM, Singh P, Khatkhatay MI. Age-related changes in sex steroid levels influence bone mineral density in healthy Indian men. Osteoporos Int. 2009 Jun; 20 (6):955-62. DOI: 10.1007/s00198008-0765-1

28. Amin S, Zhang Y, Felson DT, Sawin CT, Hannan MT, Wilson PV, et al. Estradiol, testosterone, and the risk for hip fractures in elderly men from the Framingham Study. Am J Med. 2006 May;119(5):426-33. DOI: 10.1016/j.amjmed.2005.10.048

29. Vandenput L, Ohlsson C. Sex steroid metabolism in the regulation of bone health in men. J Steroid Biochem Mol Biol. 2010 Aug;121(3-5):582-88. DOI: 10.1016/j. jsbmb.2010.03.067
30. Paller CJ, Shielst MS, Rohrmann S, Basaria S, Rifai N, Nelson W, et al. Relationship of sex steroid hormones with bone mineral density (BMD) in a nationally representative sample of men. Clin Endocrinol (Oxf). 2009 Jan;70(1):26-34. DOI: 10.1111/j.13652265.2008.03300.x

31. Ensrud KE, Lewis CE, Lambert LC, Taylor BC, Fink HA, Barrett-Connor E, et al. Endogenous sex steroids, weight change and rates of hip bone loss in older men: the MrOS study. Osteoporos Int. 2006 Sep;17(9):132936. DOI: $10.1007 / \mathrm{s} 00198-006-0088-\mathrm{z}$

32. Araujo A, Travison TG, Leder BZ, McKinlay JB. Correlations between serum testosterone, estradiol, and sex hormone-binding globulin and bone mineral density in a diverse sample of men. J Clin Endocrinol Metab. 2008 Jun;93(6):2135-41. DOI: 10.1210/jc.2007-1469

33. Fink HA, Ewing SK, Ensrud KE, Barett-Connor E, Taylor BC, Cauley JA, et al. Association of testosterone and estradiol deficiency with osteoporosis and rapid bone loss in older men. J Clin Endocrinol Metab. 2006 Oct;91(10):3908-15. DOI: 10.1210/jc.2006-0173 